\title{
Ice and water. The removal of ice on waterways in the Low Countries, 1330-1800
}

\author{
Adriaan M. J. de Kraker ${ }^{1}$
}

Received: 28 August 2015/Accepted: 5 February 2016/Published online: 6 June 2016

(C) The Author(s) 2016. This article is published with open access at Springerlink.com

\begin{abstract}
This paper looks into the blocking of ice on Dutch and Belgian rivers and canals during the Little Ice Age and how this has affected shipping and other economic activities. The key issue here is how contemporaries have dealt with such extreme circumstances during the fourteenth to eighteenth centuries. In order to address this issue the paper will give an overview of the severity of winter severity during this period. Then it continues to discuss the earliest examples of measures taken by towns to deal with frozen over canals and rivers. Information on this matter is retrieved from the late medieval town accounts of Flanders, such as Bruges which are very detailed with regard to the kind of work contractors carried out for the town. From these accounts it is clear that early in the fourteenth century ice was systematically removed and by the end of that century the first primitive ice breakers were introduced. Examples of ice removal during the sixteenth and seventeenth century, from the canals around Ghent and Brussels, demonstrate further details of large scale ice removal. By comparing ice blocking in Flanders, Holland and even Emden (Germany), and the methods used by each district one can see how systematic and similar the ice removal procedures were. Finally the introduction of the classic pre-industrial ice breaker will be discussed.
\end{abstract}

Keywords Ice coverage - Little Ice Age - Ice breaking - Shipping · Transport - Belgium · Netherlands

\section{Introduction}

This paper looks into the question of how authorities dealt with ice blocking and rivers and canals that froze over in the Low Countries (Belgium and the Netherlands). The time period studied, 1330-1800 is largely the Little Ice before the start of the industrial

Adriaan M. J. de Kraker

krakeram@Zeelandnet.nl

1 VU-University, Amsterdam, The Netherlands 
revolution, which in terms of shipping, significantly influenced the need for the ice to be broken. Ice blocking seriously interrupted transport on the canals and rivers of the study area and there was thus a need for the ice build-up to be removed as soon as possible. Because there has hardly been any research undertaken on this topic there is little or no literature to turn to, therefore this paper relies upon the investigation of primary documentary sources, such as town accounts and documents on the exploitation of barges on canals as well as the use of/and cost of ferries and tolls on bridges (de Kraker 2006, pp. 313-316). The Low Countries, 1330-1800 was a highly urbanised area in Europe with a dense network of waterways. Moreover the period is so overwhelmingly documented that a selection of locations and waterways has been made in order to make it possible to discuss the topic in greater detail.

This paper addresses at least five key issues, such as when did it start, where and how did ice removal take place? These research questions and others will be elaborated in the following section.

\section{Background and issues}

\section{Transport and waterways}

During the pre-industrial period waterways were the most generally used routes for the transport of goods. Long distance trade went overseas. On land and over much shorter distances most goods were transported by boats and barges using the many rivers and canals connecting the many towns (Filarski and Mom 2008, pp. 29-31). Especially in the coastal areas of the Low Countries with its flat and low lying landscape there was a dense network of canals and rivers. While some canals were mere remnants of old tidal channels giving access to towns such as Bruges, others were especially built and sometimes at a very early point in time, such as the narrow Lieve canal connecting Ghent to Bruges which opened in 1269. In the coastal provinces Holland, Zeeland and Friesland waterways were so vital for the economy that road transport was very difficult and when the 80 years War (1568-1648) was fought no cavalry ventured in the area at all. Here the transport network was mainly used for transporting turf, grain, salt and fish, while during the seventeenth century barges also began to transport a growing number of passengers on regular routes (de Vries 1981, pp. 26-41). Rivers remained hard to navigate both during winter time with ice and ice jams and during summer time when there was hardly enough water. To overcome some of these difficulties a special kind of boat was developed for the Dutch rivers. These were long rafts made principally from logs coming from the German principalities heading for Dordrecht (Nusteling 1998, pp. 155-158).

In the course of the sixteenth and seventeenth centuries important new canals were built connecting major towns in the Low Countries (de Vries 1981, pp. 45-47). Such public works were really big projects which could not be supported by a single town. Therefore two or more towns formed joint ventures which built the canal and then exploited it. One such canal was built between Brussels, Vilvoorde, Mechelen en Willebroek (1550-1561), another one was built in the 1640s connecting Bruges, Oostende, Nieuwpoort, Veurne and Dunkirk as a joint venture between Bruges, Veurne and Dunkirk. At about the same time Amsterdam, Haarlem and Leiden also built their canals connecting these three cities. Still towns such as Ghent built canals which they financed independently, such as the Sasse Vaart (1547-1564) giving the town direct access to the Western Scheldt to the north and 
later (1624) connecting the town with Bruges. (Decavele 1993) this connecting canal was co-financed by the Estates of Flanders.

All of the canals built during the period under discussion had to be exploited in some way or another in order to earn back the investment and to pay for the annual upkeep of the canal. This upkeep consisted of maintaining both parallel running dikes (levees), the locks along the canal as well as the bridges across the canal. Because it was seldom possible for barges on the canals to hoist their sail(s), generally horses or people were used to pull the vessels. Therefore there were paths on the canal dikes. The exploitation of canals consisted of renting out the barges which transported people between market towns, levying tolls at locks and bridges and sometimes even exploiting ferry boats crossing the canal.

The barges of the sixteenth-early ninteenth century functioned like stage coaches did on land and were the forerunners of trains during the industrial era. The barges predominantly carried passengers and some cargo. On board there were first and second class compartments where passengers were served food and drinks. Children usually travelled at half price. Barges sailed from a regular stop at a regular time, which in Bruges was the Minnewater and in Ghent was the Brugse Poort. The departure of the barge was announced by bells ringing from the nearest chapel. The journey by canal took several hours whilst the barges met halfway off Aalter (Fig. 1).

\section{The Little Ice Age}

The period 1330-1800 comprises most of the Little Ice Age (LIA). This period of which the start is still debated was a relatively colder period and lasted until the mid-ninteenth century (van Engelen et al. 2001; Bràzdil et al. 2010; Goosse et al. 2012). The LIA has both colder and warmer periods, the colder ones occur in the second half of the sixteenth and beginning of the seventeenth century (Grindelwald Fluctuation), the period 1670-1715 (Late Maunder Minimum Period) and a second colder period the second half of the eighteenth century (Dalton Minimum) (Figs. 2, 3). During severe winters waterways froze over and transport became impossible. During the severest winters, such as 1607/08, 1708/09 and 1739/40 even sections of the coastal waters were closed due to ice build-up (Buisman 2000, 2006). This made shipping on rivers and canals impossible. An additional problem for the canals were the locks, which could be damaged by the expanding ice. Usually sluices and locks in smaller canals and ditches were made ice-free in order to continue discharging water as long as possible, otherwise the low lying areas would soon suffer from flooding (Table 1).

Frozen over rivers and canals also opened up new opportunities. During the severest winters of the LIA goods were transported over the ice of the Zuiderzee from Amsterdam to Kampen. At some point in time even the Waddenzee froze over making it possible to carry goods from Friesland to the islands on wagons and carts. In Dutch art paintings and engravings depicting fun on the ice became a familiar and famous genre and were widely sought after. These images generally showed the bright side of a severe winter. People moving on the ice on skates, sledges and using sleighs. In particular the rich had a good time prancing in sleighs pulled by horses in which their ladies sat protecting their faces with masks against the cold (Roelofs 2010). Commoners, at least those that could made the best of the situation, some selling snacks, others repairing skates or fishing through holes made in the ice.

For labourers such as brick layers, farm hands the cold weather meant unemployment and the possibility of a shortage of money to buy food and fuel. 


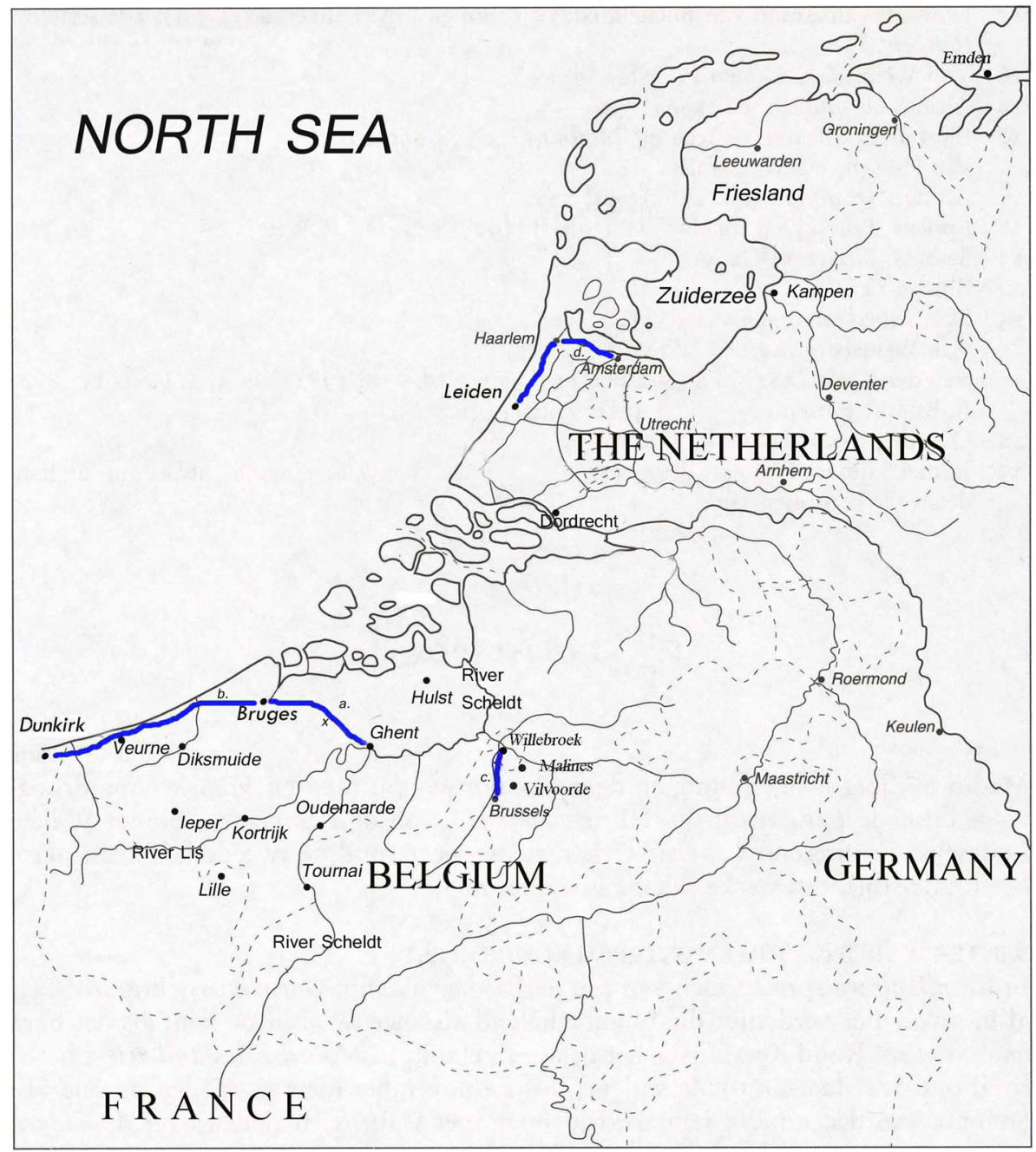

Fig. 1 Canals and towns investigated. a Canal Ghent-Bruges, b Canal Bruges-Oostende-Veurne-Dunkirk, c Canal Brussels-Willebroek, d Canal Amsterdam-Haarlem, x. Aalter

\section{The research questions}

Because there is hardly any literature on the subject of ice on waterways and ice removal in medieval times and during the Ancien Regime (1500-1800), first some basic questions need to be addressed. One of the first questions we need to ask is when did communities start to remove ice systematically from frozen over rivers and canals. In order to answer this question we need to focus on documented evidence relating to the transportation of goods and people. That is why the densely populated and highly urbanized Low Countries are considered; it is here that documentary evidence can be found and in particular Flanders where the documentary evidence offers a unique insight into the subject. 


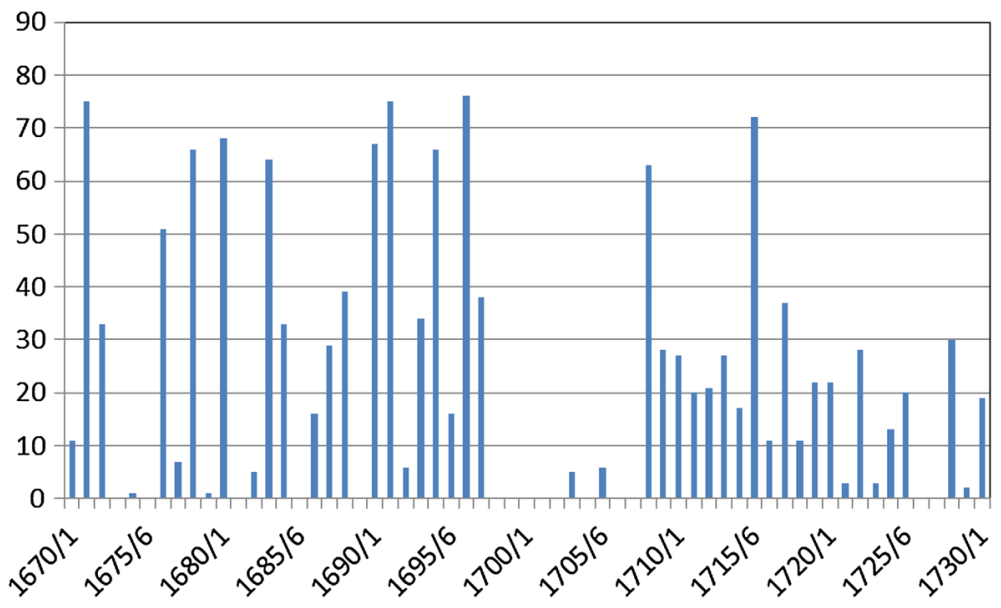

Fig. 2 Annual number of ice coverage days of canals and town moat at Bruges, 1670-1730. Source Town Archive Bruges, Series 43, 44, 46, 47, 66-75, 228-231 and 290. Each series containing 10 up to 50 accounts concerning the income of particular canal sections, bridges and repairs

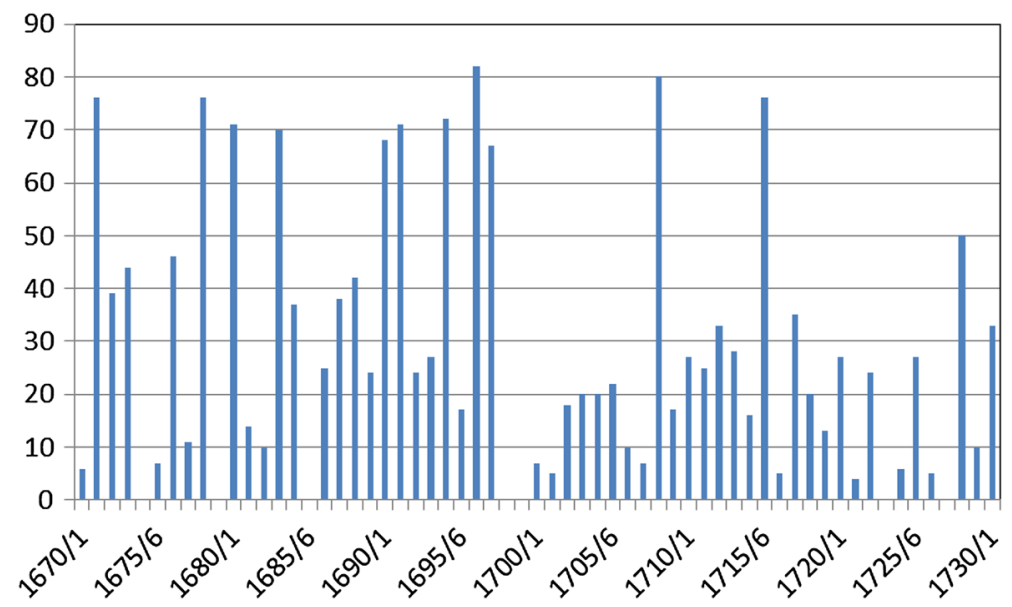

Fig. 3 Annual number of ice coverage days of canals in and around Haarlem, 1670-1730. Source NoordHollands Archief Haarlem (Netherlands), kast, nos. 1-7, 9-13, 17, 27-38, 40-44 and 48

Secondly, how was the ice removed systematically? Was this carried out by hand or were some kind of engines, machines, vessels or devices used as well? If there is evidence for systematic removal of ice, this will re-occur each year there is ice and will cost a considerable amount of money. As a result of this there must have been a highly important reason to do so, which brings us to the next question. Did people remove the ice to make way for shipping only or were there other considerations as well?

The last questions relate to the use of special vessels, boats or techniques. If evidence can be found of any kind of technical development in the use of ice breakers during the period under investigation, then when did this start and where did it start? In addition to this is it possible to establish how widespread were ice breakers used? In order to know 
this, the focus of this study will be on the $1490 \mathrm{~s}$ and how the major and small towns in and outside Flanders dealt with thick ice on town moats, rivers and canals.

\section{The data}

From the background description it will have become clear that information relating to shipping is the main source of information considered here as it relates to severe winters where rivers and canals became frozen over. This kind of information is precise in terms of date and place. Therefore we know exactly when waters closed and where. Comparing locations at different latitude Haarlem $\left(52^{\circ} 22^{\prime} \mathrm{N}\right)$ and Dunkirk $\left(51^{\circ} 1^{\prime} \mathrm{N}\right)$ already shows the shipping documentary sources provide exact information. Moreover, the data is continuous over longer periods, while other information only covers short periods (weather diary and chronicles) or only shown calculated running means (models) (Goosse et al. 2012).

The first documentary evidence comes from the Town Archive of Bruges, where a long series of town accounts is kept (Fig. 4). For this paper the period 1330-1520 has been investigated, totalling 190 annual town accounts of which about $90 \%$ is available.

For the canals connecting Amsterdam, Haarlem and Leiden there are four series of accounts on the leasing out of the barges. These archival sources are kept at the NoordHollands Archief. In these accounts the monthly income in terms of freight and passengers carried is recorded along with all the dates on which barges could not sail. Generally a reason was given for this such as 'closed water due to severe frost'. In Fig. 5 an overview of the 1690 s is given during which the canals were frozen over in January and February 1691, February 1692, January and February 1695 and also 1697. The average annual number of barges in daily use was about 6500 and dropped by between 500 and 1000 during years with severe frost. Expenses made for the repair of the canals, bridges and locks can also be found in these accounts. Finally, there are also entries relating to the costs of removing the ice.

Concerning the canals connecting Bruges, Oostende, Nieuwpoort, Veurne and Dunkirk there are seven to eight series of accounts for several sections of the canals. These documents are kept at Bruges (Town Archive), Veurne (Town Archive) and Dunkirk (Archive Municipal). The accounts record the fees for leasing out of the barges as well as dues levied on the canals (Pauwels 1992). A special mention needs to be made of entries stating the time period and the causes of the interruption of shipping on the canals. In most cases interruption occurred during severe winters when the canals were frozen over, but there could also be other reason. In summer water levels could be too low to allow shipping, there could also be warfare and under very extraordinary circumstances canals could even loose water if a wide breach in one of the levees occurred. At times of utmost danger, nobody wished to rent the barges, therefore the income was collected on a daily basis. During military campaigns barges could be confiscated for transport of soldiers and in some cases boats were even burnt in order to deprive possible use of barges by the enemy to transport troops and guns.

Another canal ran from Bruges east towards Ghent. On this canal, which opened in 1624, a lot of cargo was being shipped between both towns and a number of barges was maintained for this purpose. These barges were often leased out, and many accounts from the eighteenth century have been preserved. ${ }^{1}$ From 1675 to 1785 barges transported

1 State Archive Ghent, Estates of Flanders, nos 4916-4978, 4987-4994, 5012-5024, 6298-6332, 6352-6496, 6403, 6404, 6407 and 6409. 
between 20,000 and 30,000 passengers per year (Parmentier 1993, pp. 69-70), being about a quarter of the number of passengers travelling on the barges between Amsterdam and Haarlem.

The information on shipping on the canals from Brussels, Vilvoorde, Mechelen and Willebroek comes from the last decade of the seventeenth century and the first half of the eighteenth century. The documented series of accounts, kept at the Municipal Archive in Brussels, which initially ran from the building of the canal (1522-1561), was very badly damaged during the big fire that hit Brussels at the end of the seventeenth century (Parmentier 1993, pp. 36-38). The documents having most gaps are about the leasing out of the barges, the more complete documentary series is about the leasing out of the ferry boats. Due of the winter severity of the last decade of the seventeenth century these accounts give information about the interruption of shipping, and length of the interruption. In addition there are entries on expenses made to remove the ice in terms of duration, men and material employed.

The information about the waterways of Emden and the removal of ice, is special. In separate records the so called Ice Accounts kept at the Town Archives in Emden, there are records showing when and how the ice was removed from the access route and the port of

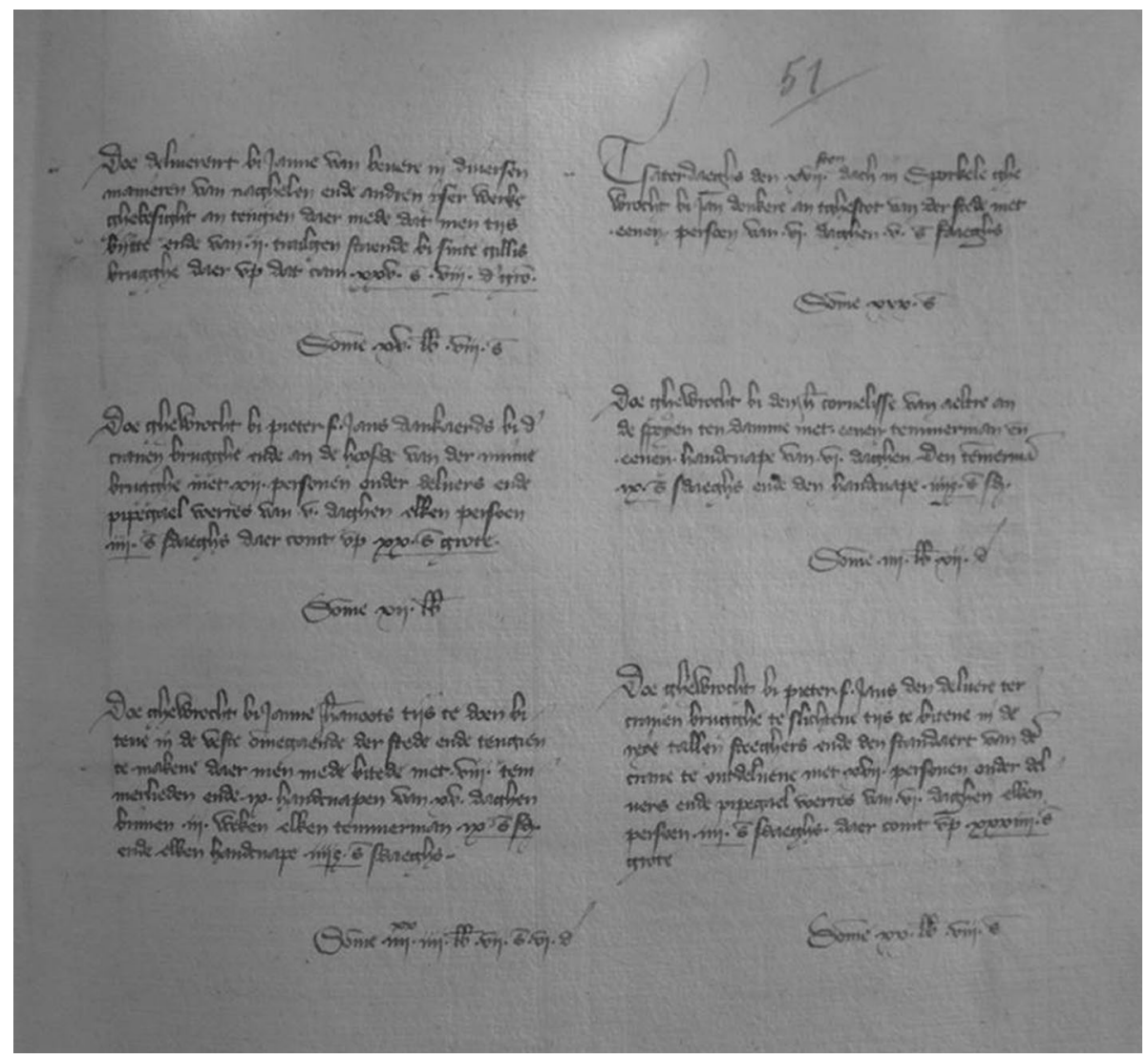

Fig. 4 Page from the town account of Bruges, 1391-1392, with entries on the removal of ice in February 1392. Source Town Archive Bruges (Belgium) town account 1391/92 


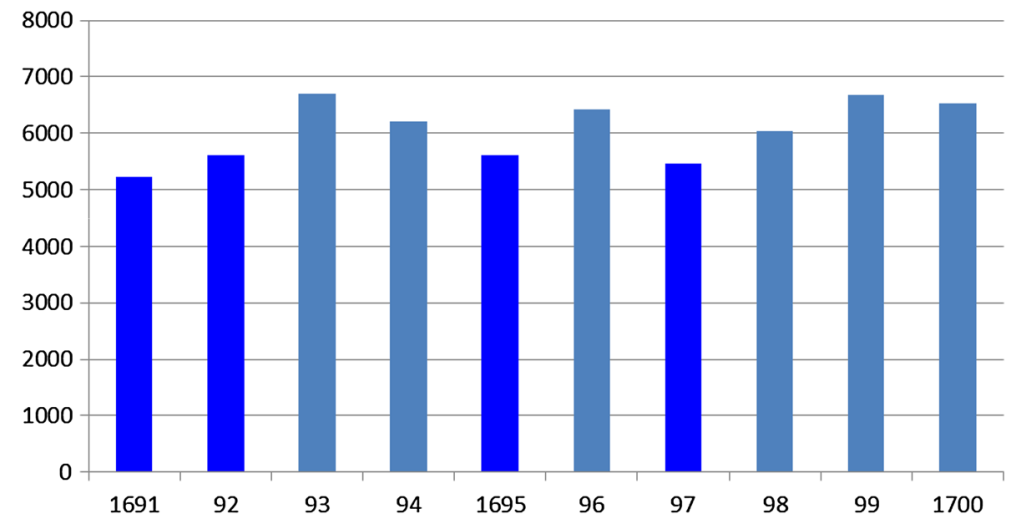

Fig. 5 Number of barges on the track between Haarlem and Amsterdam, 1691-1700. Source NoordHollands Archief Haarlem (Netherlands), kast 24, nos. 3, 9-11, 20, 21, 31 and 32. Notice the years 1691, 1692, 1695 and 1697 when the canals were closed for weeks in January and February

Emden (Uphoff 2006). This implies that all of the days when ice was removed are recorded in the first half of the accounts, while all of the receipts with largely the same details are recorded in the second half of the accounts.

A last source of information consists of engravings depicting how an ice breaker operated. These engravings are much more informative than paintings, because they do not only show details about the ice breaking but also give a description of the vessel with its special parts.

\section{Ice removal}

In this section five key locations are studied throughout the period 1330-1800 where ice was removed from canals and town moats, beginning with the oldest location.

\section{Bruges: town moat and canals}

By far the oldest recorded removal of ice comes from Bruges. In the fourteenth century the town was the commercial centre of northwestern Europe where international trade routes crossed hosting many trading companies. For the Hanseatic League Bruges was a real hub allowing the cog ships access via the Zwin inlet to Damme where most goods were transferred onto smaller vessels.(Ryckaert 1982; Unger 1980). The town of Bruges was surrounded by a large moat which was connected to some smaller canals. As a trading centre access to its port and the continuing of trade as long as possible during the winter were vital. This implied that ice had to be removed at all times and at all costs during severe winters.

In the town account of 1333/34 there are records, from 25 December 1333 (n.s. 2 January 1334) onwards, showing ice was removed at the sluice of Damme and some other places. ${ }^{2}$ Further information on the duration of ice is missing, but judging from the kind of

2 Town Archives Bruges (Belgium) (TAB), town account 1333/34, fol. 83ro. 25 December 1333 would be 2 January 1334 new style). 
public works carried out there were none for two weeks in a row, which suggests this situation to have lasted until 6 or 7 January 1334. (n.s. 14 or 15 January 1334). Also during the winter of 1339/40 ice had to be removed during the week of 18 December and 25 December 1339, and again in the week of 29 January 1340 (n.s. 6 February 1340), whilst that same week the gutters of the town hall had to be cleared of snow (Table 1). ${ }^{3}$

In the town account of 1355/6 it is recorded that from Saturday 26 December 1355 (n.s. 3 January 1356) ice was removed from the town moat by sixteen labourers working for some 4 days. ${ }^{4}$ They were assisted by a vessel, which was not specified. So the ship could have been a boat taking the crew to another part of the town moat. Again on 12 January 1359 (n.s. 20 January 1359) ice was removed from the town moat. ${ }^{5}$ This was carried out by a number of labourers over a period of 4 weeks. During that fourth week thaw had already set in, because the crew also had to fight an abundance of meltwater passing through the Bruges' canals. There is no mentioning of the use of boats during this period.

In January and February 1364 (n.s. 14 January-3 February 1364) ice had to be removed and as it was too thick by mid-January that it had to be guarded (see Discussion). ${ }^{6}$ In the following next years the same thing occurred during severe winters.

During December 1382 and January 1383 the township utilised a boat built by Jan Soyen, who was mentioned as ship builder, to break the ice in the town moat. ${ }^{7}$ The ship, in fact the first primitive ice breaker, started work on Saturday 3 January 1383 (n.s. 10 January 1383) and was used until the beginning of February 1383. During that winter the ice was removed by labourers and from 19 December 1382-29 January 1383 (n.s. 25 December 1382-2 February 1383) the ice breaker was again used. Apparently the use of an ice breaker was such an overwhelming success that the township bought four such ships. ${ }^{8}$ During the winter of 1391/92 the ice breaker is mentioned as an engine to break the ice, which at that point in time needed repair. ${ }^{9}$ Except for the winter of 1407-1408 when all the waterways were closed again, ice breaking occurred only very occasionally.

In the autumn of 1452 things changed. The townships hurried to have all the ice breakers repaired before the winter had even begun and ordered them to standby from August 1452 until September 1453. Although nothing about the actual breaking of the ice during that period is known, it must have been an extraordinary period (see Discussion). ${ }^{10}$

From 1454 onwards the town paid a regular fee to master Anthuenis Goossins, one of the guild masters, for the annual removal of ice. ${ }^{11} \mathrm{He}$ and his day labourers had to remove the ice at a location called Seven Doors (place where the locks are) and some cays on a number of occasions. In 1483 ice removal did not happen quickly enough, therefore extra men were employed. ${ }^{12}$

\footnotetext{
3 TAB, town account 1330/40. 18 December 1339 (n.s. 26 December) 25 December 1339 (n.s. 2 January 1440) and 29 January 1440 (n.s. 6 February 1440). Concerning snow removal no dates are given.

4 TAB, town account 1355/56, fol.86vo.

5 TAB, town account 1358/59, fol.72ro-vo.

6 TAB, town account, 1363/64, fol. 79vo-80vo.

7 TAB, town account, 1382/83, fol. 108ro-113ro.

8 TAB, town account, 1382/83, fol. 158ro.

9 TAB, town account, 1391/92, fol. 51ro.

$10 \mathrm{TAB}$, town account $1352 / 53$, fol. $45 \mathrm{vo}$ and $48 \mathrm{vo}$.

$11 \mathrm{TAB}$, town account, $1454 / 55$, fol. $34 \mathrm{vo}$.

12 TAB, town account, 1483/4, fol. 165ro.
} 
Table 1 Days of ice removal on the Bruges town moat and canals, 1334-1452

\begin{tabular}{|c|c|c|c|c|}
\hline Year & Month & Days & Working days & Further details \\
\hline 1334 & Jan. 2-16, Feb. 27 & 15 & No data & Day labourers \\
\hline 1335 & Jan. 15, Feb. 12-26 & 15 & No data & Day labourers \\
\hline 1336 & Feb. $11-17$ & 6 & No data & Day labourers \\
\hline 1337 & Feb. 19-26 & 6 & No data & Day labourers \\
\hline 1339 & Jan. 23-29, Dec. 25-31 & 12 & No data & Day labourers \\
\hline 1340 & Jan. 1-7, Feb. 5-11 & 13 & No data & Day labourers \\
\hline 1341 & Dec. 23-29 & 6 & No data & Day labourers \\
\hline 1342 & Jan. 27-Feb. 1 & 6 & No data & Day labourers \\
\hline 1347 & Jan. 28-Feb. 2 & 6 & No data & Day labourers \\
\hline 1355 & Jan. 3-7 & 4 & 64 & Ship \\
\hline 1359 & Jan. 20-Feb. 14 & 25 & 125 & \\
\hline 1364 & Jan. 14-Feb. 15 & 33 & 330 & Incl. snow clearance \\
\hline 1367 & Feb. 21 & 1 & 13 & \\
\hline 1369 & Dec. $23-30$ & 8 & 64 & \\
\hline 1371 & Feb. 23-27 & 5 & 35 & \\
\hline 1372 & Mar. 13 & 1 & No data & Incl. snow clearance \\
\hline 1381 & Jan. 27-Feb. 9 & 14 & No data & \\
\hline 1382 & Feb. 3, Dec. 25-31 & 8 & No data & \\
\hline 1383 & Jan. 1-Feb. 2 & 33 & No data & 4 ice breakers \\
\hline 1392 & Feb. 18-Mar. 8 & 20 & 320 & 2 or more Ice breakers \\
\hline 1396 & Jan. 30-31 & 2 & No data & \\
\hline 1399 & Feb. 9-15 & 7 & 28 & \\
\hline 1402 & Dec. 26-31 & 6 & & \\
\hline 1403 & Jan. 1-Feb. 9 & 40 & Frozen over & No action \\
\hline 1408 & Jan. 6-Feb. 20 & 46 & Frozen over & No action \\
\hline 1420 & Jan. 15-20 & 5 & No data & \\
\hline 1448 & Feb. & 13 & No data & During nights \\
\hline 1452 & Nov. & & No data & Large scale ice clearing \\
\hline
\end{tabular}

Source Town Archive Bruges (Belgium), town accounts 1333-1452

Finally the severe winter of 1490-1491 needs to be mentioned. At that point in time the township apparently had neglected the maintenance of their ice breakers, because at least two vessels had to be rented from skippers. ${ }^{13}$ For the remaining three decades nothing unusual happened during these winters. A fixed amount of money was spent on ice removal by a master and his day labourers irrespective of whether the winter was mild or severe.

The sixteenth century and most of the seventeenth centuries do not yield high quality information about ice removal. One reason is the Eighty Year's War (1568-1648) which has affected shipping profoundly, another reason are the many gaps that occur in the longterm series of accounts on the leasing out of barges, levying tolls etc. Therefore the next time period studied starts towards the end of the seventeenth century and is the start of the Late Maunder Minimum Period.

13 TAB, town account, 1490/91, fol. 150vo-156ro. 


\section{Brussels canal}

The waterway between Brussels and Mechelen was a busy route, with a lot of barges and other merchant vessels using this route, as documented in the accounts of the toll office at Willebroek. In January 1694 frost set in during the first week and ice began to form on the canal (de Kraker 2006, p 315; Buisman 2000, pp. 199-205). On 10 January 1694 an ice breaker began to remove the ice, working until the 16th of January $1694 .{ }^{14}$ Ice was removed on the canal section running from Brussels as far as the River Rupel. Also during the next short cold period the ice breaker was at work. Both these actions proved to be successful. The following winter the canals were frozen over from around Christmas 1694 until the end of February 1695. There is no mentioning of ice breakers being at work continuously. The ice was so thick that the canals remained closed until 23 February 1695. By the end of February and also during the first days of March 1695 extra horses were hired to pull the icebreaker and then it took another 3 days to remove the ice on the canal section from Brussels as far as the River Rupel. ${ }^{15}$ During the winter 1696-1697 there were two distinctive cold periods. The first one started a week before Christmas of 1696 and lasted until the first week of January 1697. On the 6th and 7th of January 1697 the icebreaker could be operated. But then the second much colder period started which caused the canals to be frozen over from 24th January until 23rd February 1697. When it became clear that thaw had set in, around the 2nd March, the icebreaker could start removing the ice. ${ }^{16}$ In February 1698 ice breaking occurred for the last time during that very cold decade of the seventeenth century.

Neither the accounts on the exploitation of the canal, nor the ferry records, specify how or when the icebreaker was used, Nor are we able to find details for the construction or repair of the ice breakers, although details of the need to use horses-normally used to power the ice breakers is recorded. One thing that can be concluded is that after a very severe winter it usually took about 3 days to remove all of the ice from the canals or to make it navigable at the least.

\section{Amsterdam-Haarlem-Leiden canals}

From when the canals were originally built, between the towns of Amsterdam, Haarlem and Leiden ice was removed. The sheer number of boats and barges using the canal and the number of passengers travelling by barge demonstrate the huge economic interest in the canals (de Vries 1977).

As soon as the canals could not be used for weeks or months on end, which was the case during some severe winters in the 1690s, ten thousand or more passengers less were carried resulting in some 1000 fewer barges being used each year. There were two ways of coping with the ice. One was to use extra horses to pull the barges along the towpaths or to remove the ice using ice breakers.

Most of the time barges used extra horses to allow them to make headway through the ice, as long as this was possible (e.g. ice became too thick). So in January 1741 there were only 60 barges going from Leiden to Haarlem and back, while double that number was the average, In January and February of 1742 extra horses were needed to be used on the same

\footnotetext{
14 Town Archive Brussels (Belgium), Kanaal, no 811 (1693/94), fol. 242ro and fol. 329ro.

15 Town Archive Brussels, Kanaal, no 2565 (1694/95).

16 Town Archive Brussels, Kanaal, no 2567 (1696/97).
} 
canal section. ${ }^{17}$ If we exclude this period of cold weather and that experienced during February 1740 there was not one month that barges could not use this section during the rest of the 1740's, but further extra horses were used during 1744 (February), 1745 (January, February), 1746 (February, March), 1747 (January, February), 1748 (JanuaryMarch), 1749 (February) and 1750 (January). ${ }^{18}$ The 1780 s were quite the opposite with the canals completely frozen during January 1780, February 1784, January 1787 and January $1789 .{ }^{19}$

From the moment extra horses pulling the barges through the ice were unable to do their job properly ice breakers were used. But even ice breakers could not break the thickest ice, therefore the canals were closed 1 or 2 months during the severest of winters. On the Amsterdam-Haarlem-Leiden canals ice breakers were used from the start. In January, February and early March 1636 a lot of repairs to the ice breakers occurred. This is reflected in the fact that iron was purchased for these repairs. ${ }^{20}$ Also from 1637 till 1641 serious repairs occurred, but the biggest one dates from 10th January 1656 when some 1300 guilders worth of repairs were carried out. ${ }^{21}$

Focussing on the last decade of the seventeenth century demonstrates an intensive use of the ice breakers. This becomes apparent from the many repairs and the purchase of extra iron plates during this period. In 1691 nine plates of German iron were bought, while on 16 January 1696 Swedish iron plates were purchased. ${ }^{22}$ In the next year steel rods and again some Swedish iron plates were bought, all of which were installed on the bottom of the ice breaker.

From an engraving of an icebreaker made in the 1730s it becomes clear how such a vessel was built and how it operated on the canals removing the ice (Fig. 6). Such a boat is operated by a dozen men of which six work on the vessel, while the others are on the ice or the levee of the canal. The boat has a broad and flat prow with several rods bending down. Between the rods iron plates have been installed. Because the boat needs to split the ice in front of it there is an extra weight of 18,000 pound at the foredeck pushing the prow downwards causing the thick ice to break. The ice blocks move underneath the boat and re-emerge at the stern. There the blocks are measured and handled to be sold to private persons in their ice-cellars. On the icebreaker there is a very strong mast to which two thick and long ropes are fastened. Around the mast there are many hooks, axes and saws. The saws were used by men checking the ice in front of the boat and trying to saw some parts into pieces, which is depicted on another engraving of an ice breaker at work. Finally the two ropes go towards two packs of horses, both packs consisting of twenty horses, totalling 40 horses pulling one big ice breaker through the ice. Because the distance between the ice breaker and horses is quite large and the noise of breaking ice and working horses is loud, the commander on the ice boat uses a primitive loudspeaker to command the horse drivers.

\footnotetext{
17 Noord-Hollands Archief, Haarlem (The Netherlands), Trekvaart Kast 24, no 59.

18 Noord-Hollands Archief, Trekvaart kast 24, nos 59 and 61.

19 Noord-Hollands Archief, Trekvaart kast 24, no 68.

${ }^{20}$ Noord-Hollands Archief, Trekvaart nr. 5913. Entries of 16 January 1636, 7 February 1636 and 13 March 1636.

21 Noord-Holland Archief, Trekvaart nr. 5913, Year 1656 (10 January 1656).

22 Noord-Hollands Archief, Trekvaart nr. 5914, Year 1691 and 1696.
} 


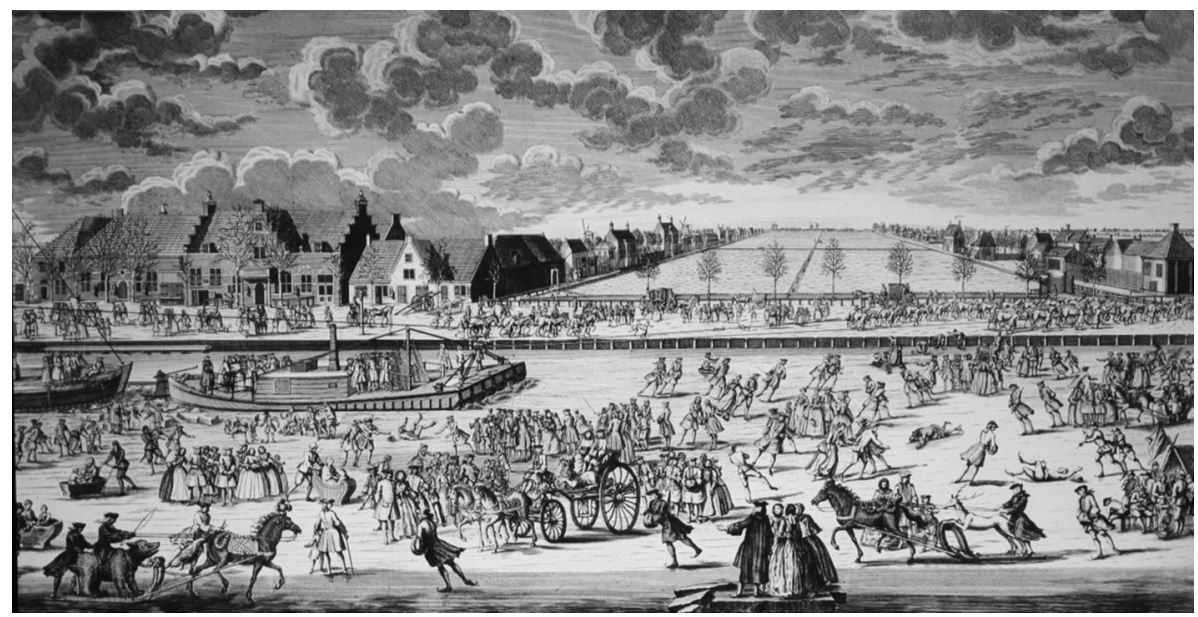

Fig. 6 The Amsterdam ice breaker at work in 1733 (Amsterdam Town Archives, Beeldbank)

\section{Ghent-Bruges canal, 1780s}

The canal that ran between Ghent and Bruges was frozen over regularly, for short periods of time during the 1780s. The winter of 1785-1786 gives an impression of the way ice was removed and the canal was kept navigable when there was a period of frost from December 1785 until the 8th of January 1786 and a second frost period that lasted from the end of February 1786 until the second week of March 1786 (Fig. 6) (Buisman 2015, pp. 672-686). On most of those days extra horses were hired to pull the barges through the ice. One of the barges already doubled the number of horses on 9th December 1785 adding another one a day later. But on the 27th of December 1785 still more horses were needed and already the next day the icebreaker had to be used with it being necessary for a barge to follow directly behind it. The following day three teams of horses were needed in order to pull one of the barges which was preceded by an icebreaker. In total that winter the icebreaker was used for eight days. In March 1786 the only way to get through the ice was with the ice breaker breaking the ice, utilising several teams of horses, directly followed by a barge also pulled by two or more horses.

Further east of Bruges ice breaking occurred as far as Aalter bridge, which is halfway between Bruges and Ghent, while another icebreaker worked its way through the ice from Ghent westward towards Aalter bridge. At Ghent there was a special place where a lot of the ice was collected, called the IJsput (ice pit). At Bruges near the Minnewater, where the barges departed each day there was also an ice pit in which the ice blocks were stored. ${ }^{23}$

During 1786 ice breakers were used again on the same track canal section, starting on 15th-18th November and also the 24th December, while they resumed ice breaking on the 28th December with three teams of horses pulling the ice breaker. On 16th January 1787 the ice breaker was again used, pulled by two teams of horses (Fig. 7). ${ }^{24}$

\footnotetext{
23 State Archives Ghent (Belgium), Estates of Flanders, no 6384 (1785/86) and no. 6410.

24 State Archives Ghent, Estates of Flanders, no 6411 (1786/87).
} 


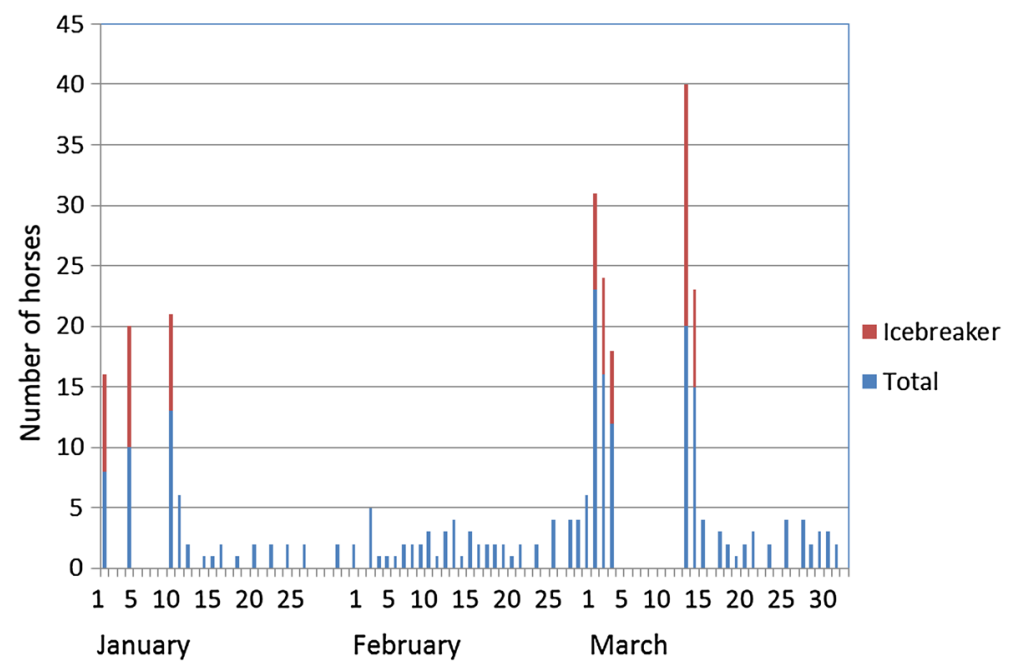

Fig. 7 Daily number of extra horses used on the Ghent-Bruges canal in 1786. Source State Archives Ghent (Belgium), Estates of Flanders, nos. 6384 and 6410

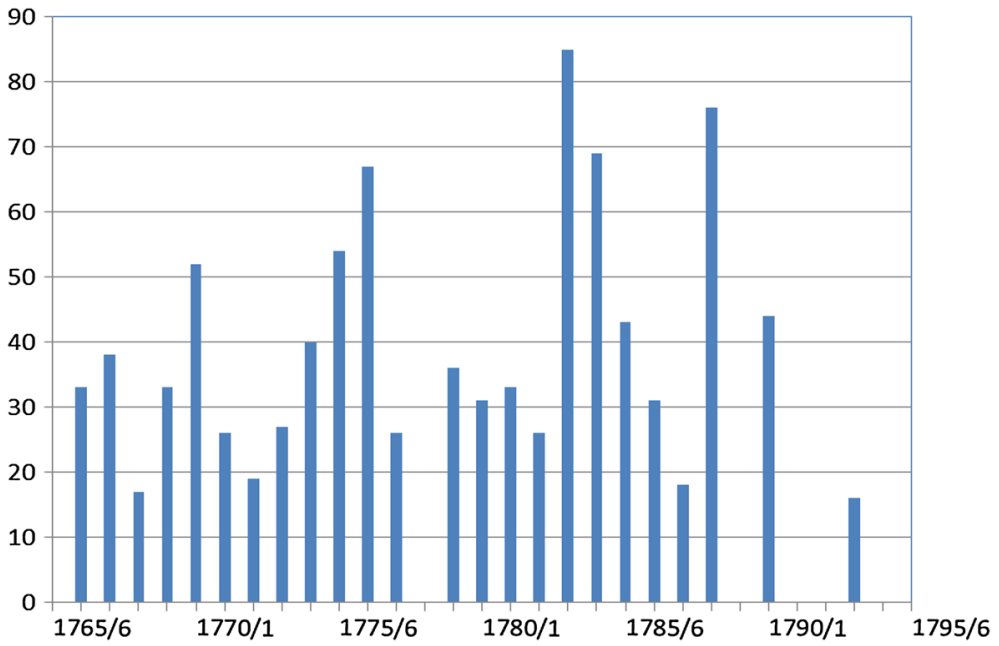

Fig. 8 Ice coverage days at Ghent-Bruges and ice removal, 1765-1795. Source State Archives Ghent (Belgium), Estates of Flanders, nos 6366-6440

Also during the severe winters of the last decade of the eighteenth century the ice breaker was frequently used and no documentation points to any change, during that century, to the method used to remove ice except by using extra horses to pull the barges and the use of icebreakers pulled by sometimes as many as three teams of horses.

During the winters of 1783-1784 (Buisman 2015, pp. 621-672) a lot of repairs to the two ice breakers needed to be carried out. ${ }^{25} \mathrm{~A}$ look at the length of the ice breaking occurrence during those winters clearly demonstrates the intensive use of both vessels (Fig. 8).

25 Town Archives Emden, 20 Eiselgelder Rechnungen, nos 17-18 (1783/85). 


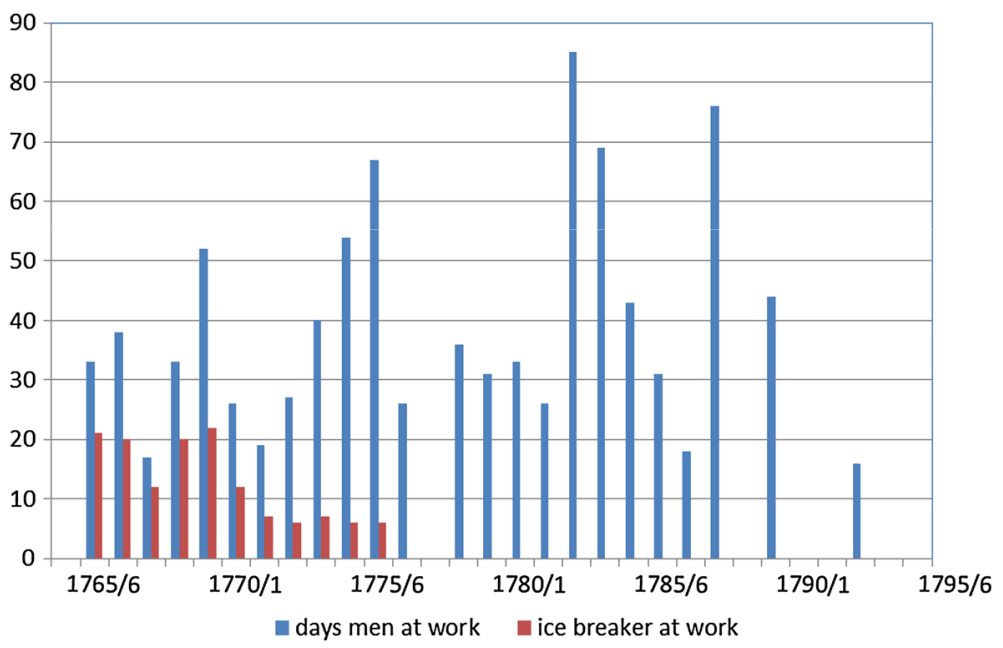

Fig. 9 Days of ice coverage at Emden, 1765-1795. From 1777 onwards the days on which ice breakers were used are not specified anymore. Source Town Archiv Emden, 20 Eiselgelder Rechnungen 1-27

\section{Emden town and harbour}

Every winter the harbour and the access to the town of Emden and its town moat were frozen over, therefore the township employed a boat and many labourers to remove the ice. Ice removal at Emden can only be reconstructed for the second half of the eighteenth century, because the Eiselgelder Rechnungen records have only been preserved from 1766 to 1767 onwards. There were two ways in which ice was removed: one being the employment of labourers using axes and hooks, the second being the employment of a boat or ice breaker. The records hardly give any specific information about the further equipment of the boat. The records mentioning the ice breaker occur at times when the vessel needed repair or a new vessel was built, e.g. in September 1772 when extra iron was delivered. $^{26}$ The yearly records mention all the days on which men worked to remove ice using axes and hooks or when the boat (ice breaker) was used. Constructing a time line for all of the days on which there was ice (Eisel), per winter season, clearly demonstrates that the ice breaker was employed on days when the men with axes and hooks were not working on the ice. With the introduction of a second ice breaker in 1777 the need for manual ice clearance became unnecessary. ${ }^{27}$

Looking at three decades of ice coverage at Emden one can see that ice was removed during 24 winters (Fig. 9).

\section{Discussion}

In order to study ice removal in the Low Countries and in order to detail it as far back in history as is possible it is necessary to obtain the oldest, most detailed and highest quality documentary evidence possible. These three criteria seldom go together, therefore the

\footnotetext{
26 Town Archives Emden (Germany), 20 Eiselgelder Rechnungen, no 8 (1773/74(25 September 1774).

27 Town Archives Emden, 20 Eiselgelder Rechnungen, no 11 (1776/77) and no 12 (1777/78).
} 
decision was made to study the oldest continuous series of a medieval town records, which at that time, was at the heart of International trade. Many waterways had to be protected and made navigable the whole year round. The documentary situation at Bruges proved to be an excellent start for documenting ice removal. As a political power in Flanders, with about 40,000 inhabitants, it was at the heart of overseas trade. But most important of all was the almost complete series of town accounts which date from 1330 onwards. From this it has become clear that ice removal from canals and the big town moat was a regularly reoccurring public work. The entries state it was carried out by a special guild or a regular group of day labourers with the assistance of a boat. In 1383 it only becomes clear that a special boat or engine (engien) was used to break the ice and more specifically built that very year. So there is some certainty that ice removal started in Bruges in the early fourteenth century, probably already in the course of the thirteenth century, at a time when the town was already an international trade centre halfway between Northern Europe and the Mediterranean. Comparing Bruges and Ghent, however, it cannot be excluded that Ghent could have been earlier in introducing systematic ice removal and utilising special ice breakers, because the town lay at the conjunction of the River Lis and River Scheldt. And to prevent the town from flooding Ghent had already developed an ingenuous system of hydraulic engineering works (Gelaude 2010).

Was Bruges the exception or was ice removal also common in other areas of the Low Countries? During the Middle Ages there was considerable traffic between the major towns such as Tournai, Lille, Ghent, Brussels, Dordrecht, Utrecht and others. Many merchants from the towns and outlying areas mentioned, frequented Bruges. From the town account of Bruges this is confirmed by the numerous entries of messengers sent to all of these towns and areas in the Low Countries and to an even wider area, including the North German towns. The town also welcomed the many envoys of these towns and outlying areas. On special occasions the town asked for expert knowledge from specialist in Tournai, Dordrecht, Antwerp, Middelburg and even the (at that time) very small town of Amsterdam. So there can be little doubt about the exchange of new ideas, technical and hydraulic engineering knowledge within the Low Countries at the time.

A check of how thick ice was dealt with by smaller towns during the severe winter of 1491-1492 in Flanders clearly demonstrates that the use of ice breakers was already widely spread during the fifteenth century. At Oudenaarde, located on the River Scheldt, probably one ice breaker operated for at least 26 days on the removal of ice. ${ }^{28}$ At Kortrijk, located on the River Lis, ice breakers spent 6.5 days on the removal of ice, while at Veurne same thing happened. ${ }^{29}$ At Ieper ice removal by several ice breakers was carried out, which took them a total of 10.5 days. Ice was so thick that the vessels needed continuous repair. ${ }^{30}$ Whereas Ieper was one of the major towns in south Flanders, Veurne was smaller. Diksmuide, a small market town on the River IJzer, also had to remove the ice off its waterways for which it used ice breakers and many day labourers. It took the small town 339 working days to constantly remove the ice during the winter of 1491-1492. ${ }^{31}$ A final example of the use of an ice breaker comes from the small harbour town of Hulst in northern Flanders. ${ }^{32}$

\footnotetext{
${ }^{28}$ National Archives of Belgium, Brussels, Auditory of Flanders, (NAB, AoF), no. 31791.

29 NAB, AoFl, nos. 33236 and 4621 (fol. 22vo).

$30 \mathrm{NAB}, \mathrm{AoFl}$, no 38716, fol. 45vo-48ro.

31 NAB, AoFl, no. 34102, fol. 37ro-40vo.

32 Municipal Archives Hulst (The Netherlands), town accounts, 1488/89 and 1491/92.
} 
Going further to the north in the Low Countries winters were more severe and therefore ice removal was more problematic. Whether ice breakers were in use at that early point in time in the Holland province cannot be attested. However, the harbour town of Dordrecht did remove ice clinging to the harbour walls in January $1490 .{ }^{33}$ At that time the town's trade already had declined very sharply, so it must have been building on a long term experience in many fields, including the removal of ice. It is only at the start of the seventeenth century that there is clear evidence of the use of ice breakers, which began to operate on the Amsterdam-Haarlem-Leiden canals.

The reason why ice removal occurred is obvious from an economic point of view, because canals and rivers that cannot be used hamper shipping and trade causing merchants, towns and others to lose money. The town of Ghent collected a variety of dues and tolls on shipping on the canals and rivers running across the town. Considering the yield of some dues in January and February during the period 1680-1720 (80 months), there was no reception at all during a total of 13 months, while another 2 months did not yield anything because of warfare. ${ }^{34}$

Towns in particular had more reasons to remove the ice. One was for safety reasons during the night, when usually all the gates were closed, but especially during a time of war, when enemy attacks could occur during the daytime. For this very reason Bruges had all the ice breakers stand by during 1452-1453. No enemy would venture to cross an over frozen moat. Also smaller towns had the ice removed during warfare. In particular during the Eighty Year's War (1568-1648) many towns yearly had the ice broken in their moats when rumours about approaching enemy armies circulated. The already mentioned small harbour town of Hulst broke the ice at least during six winters (1573-1598). ${ }^{35}$

A third reason was to have easy access to water for extinguishing fires. Again the town of Bruges had a perfect organisation for the extinguishing of fires during which people could get water from the town fountain, moat and canals if a building on fire was close to the town moat or a canal.

A fourth reason was public health. Water was made available for all by breaking the ice at regular times during a severe winter.

A fifth reason was taxation and again at Bruges it was lucrative to cross the ice of a town moat not paying dues and tolls at the toll office. If the ice was broken such an 'illegal' route was cut off.

But what was the most important factor in determining the need for the ice to be broken ? No doubt safety during time of war or when the threat of war was paramount. Again even the smaller towns in Flanders broke the ice during the war years of the early 1490s, but during the severe winters of for instance $1436-1437$ or some later ones ${ }^{36}$ no public money was spent on the breaking of the ice, except for Bruges where economic motives remained important throughout the period under study.

Then there was the issue of technological development with regard to ice removal. There is hardly any doubt that day labourers using axes and hooks already starting in the fourteenth century used quite different tools from those used in the 1800s. As to the development of the special vessel used to break the ice, the town account of Bruges does not give a lot of technical details which can be used to reconstruct a technical specification

\footnotetext{
33 Municipal Archives Dordrecht (The Netherlands), no 438, (town account 1489/90, fol. 331-332).

34 Municipal Archives Ghent (Belgium), series 416 and 418.

35 Municipal Archives Hulst, town accounts, 1573-1598.

36 NAB, AoFl, nos 33183-22185 (Kortrijk, years 1436-1438), 38976-38977 (Ieper, years 1436-1437), 34049-34050 (Diksmuide, years 1436-1437).
} 
for the vessel. It is only said that it was an 'engien' or machine, and building engines of whatever kind was not uncommon in Bruges, such as the big crane, the ships locks, fountains, bridges, etc. Ieper had some small ships equipped to serve as ice breakers, while at Diksmuide two special barges were equipped by ship builders to serve the purpose. How many men operated these vessels is unknown, but at Ieper they were also using shovels and a kind of barrels to bail out water or ice. Entries in the seventeenth century accounts of the barges using the Amsterdam-Haarlem-Leiden canals do not give more information than the purchase of iron plates, German or Swedish, and ropes. The same kind of materials are mentioned in the accounts of the Brussels canal.

It is only at the end of the seventeenth century that the ice breaker emerges as a distinctive and special vessel. A short analysis of the 1730s engraving tells us that this ice breaker was built in 1696 by the brewer's guild of Amsterdam. The reason for building it is most probably due to the severe winters of that decade (Buisman 2006, pp. 165-249).

Looking beyond the period under study to the ninteenth century, due to the impact of the industrial revolution, the construction of the ice breaker changed very quickly and very thoroughly. Vessels were built with a protruding prow which was completely re-enforced with iron which also extended largely to both sides of the ship. No doubt the basic idea now was that with the ice boat slicing through the ice the ice could now disappear along the sides. Most probably the day labourers with axes and hooks became redundant too.

\section{Conclusions}

During the Little Ice Age canals and rivers regularly froze over. This hampered shipping and transport over the many waterways of the Low Countries. The study of documentary sources from the period 1350-1800 from six key locations (Bruges, canal Bruges-VeurneDunkirk, canal Ghent-Bruges, canal Brussels-Vilvoorde, canals Amsterdam-HaarlemLeiden and the town of Emden) and some additional towns, made it possible to cover the entire period, from the very beginning of ice removal. The removal of ice took place on town moats and canals though hardly on rivers where water was always running and very dangerous blocking of ice and ice dams might occur at river bends.

Ice removal had already become a regular re-occurrence during wintertime in the Flemish towns of Bruges and Ghent in the fourteenth century and most likely must have already started in the thirteenth century. Then ice was removed by day labourers with hooks and axes, sometimes assisted by a boat. In 1383 the town of Bruges had an ice breaker built. Taken into account the central position of Bruges at that point in time as an international trade hub, knowledge of ice breaking and the ice breaker must have spread across the Low Countries. In the course of fifteenth century the use of ice breakers in Flanders (Oudenaarde, Kortrijk, Ieper, Veurne, Diksmuide and Hulst) was already well established. During the seventeenth century every town of some importance in the Low Countries must have had an icebreaker in order to keep their waterways clear of thick ice. On the Amsterdam-Haarlem-Leiden canals ice breakers were used from the start.

The construction of the oldest ice breakers remains unclear. Certainly before 1500 most vessels serving as ice breaker were mere re-equipped barges and boats. It is only in the course of the seventeenth century that specifications and detailed engravings show that the vessel had a rectangular prow re-enforced with iron rods and plates. Due to its heavy weight it pushed down on the ice, breaking it. Dozens of horses were used to pull the largest vessels. Still ice breakers were operated in co-operation with men with axes, saws 
and hooks on the ice. The basic concept of the ice breaker of the late seventeenth century did not really change until the dawn of the industrial revolution which took off in the ninteenth century in the Low Countries.

The reason why ice was removed was not merely an economic one. At times of danger or warfare, town moats had to remain open water. Also public health in terms of access to drinking water was important in towns and so was public safety during town fires. Besides the town of Bruges made an effort to close off illegal passages along tolls, by removing the ice of the town moat.

Finally, more research on ice breaking in more northerly located towns in the Low Countries could provide more information on the dates when ice was removed and the technique used to remove the ice. Apart from the ice removal at Emden, more information on ice removal from countries neighbouring the Low Countries could provide information on the international spread of the knowledge used to deal with thick ice.

Open Access This article is distributed under the terms of the Creative Commons Attribution 4.0 International License (http://creativecommons.org/licenses/by/4.0/), which permits unrestricted use, distribution, and reproduction in any medium, provided you give appropriate credit to the original author(s) and the source, provide a link to the Creative Commons license, and indicate if changes were made.

\section{References}

Bràzdil R, Dobrovolný P, Luterbacher J, Moberg A, Pfister C, Wheeler D, Zorita E (2010) European climate of the past 500 years: new challenges for historical climatology. Clim Chang 101:7-40

Buisman J (2000) Duizend jaar weer, wind en water in de Lage Landen, vol 4. Uitgeverij Van Wijnen, Franeker, pp 1575-1675

Buisman J (2006) Duizend jaar weer, wind en water in de Lage Landen, vol 5. Uitgeverij Van Wijnen, Franeker, pp $1675-1750$

Buisman J (2015) Duizend jaar weer, wind en water in de Lage Landen, vol 6. Uitgeverij Van Wijnen, Franeker, pp 1750-1800

de Kraker AMJ (2006) Historical climatology, 1950-2006. An overview of a developing science with a focus on the Low Countries. BelGeo 3:307-339

de Vries J (1977) Histoire du climat et économie: des faits nouveaux, une interpretation différente. Annales, Economies, Sociétés, Civilisations 32:198-226

de Vries J (1981) Barges and Capitalism. Passenger transportation in the Dutch economy (1632-1839). HES Publishers, Utrecht, $368 \mathrm{p}$

Decavele J (1993) I. De Zuidleie: het kanaal van Gent naar Brugge. In: van den Kerkhove A (ed) Een trekschuit voor koningen, barge tussen Gent en Brugge, Drukkerij L. van Melle, pp 1-28

Filarski R, Mom G (2008) Van transport naar mobiliteit. De transportrevolutie 1800-1900. Walburg Pers, Zutphen

Gelaude Fr (2010) Waterbeheer in een middeleeuwse grootstad: stuwen en dammen te Gent $\left(12^{\mathrm{e}}-14^{\mathrm{e}}\right.$ eeuw). In: Deligne Ch, Soens T (eds) Jaarboek voor Ecologische Geschiedenis. Special issue Steden en water. Academia Press, Verloren, pp 33-52

Goosse H, Crespin E, Dubinkina S, Loutre MF, Mann ME, Renssen H, Sallaz-Damaz Y, Shindell D (2012) The role of forcing and internal dynamics in explaining the "Medieval Climate Anomaly'. Clim Dyn 39:2847-2866. doi:10.1007/s00382-012-1297-0

Nusteling H (1998) Strijd om de binnenvaart. In: Frijhoff W, Nusteling H, Spies M (eds) Geschiedenis van Dordrecht van 1572-1813. Verloren, Hilversum, pp 149-169

Parmentier J (1993) II. Een vermaeck'lijck treck-schuytje. Een spiegel van de trekvaart in de Nederlanden tijdens de $17^{\text {de }}$ en $18^{\text {de }}$ eeuw, Stadsbestuur Gent (ed.) Een trekschuit voor koningen. De barge tussen Gent en Brugge. Drukkerij Van Melle, Gent, pp 29-72

Pauwels W (1992) Het openbaar vervoer in Vlaanderen, 1640-1840 met als centraal gegeven het Nieuw Gedelf. Biekorf 92/2, 155-178 and 92/3, pp 252-264

Roelofs P (2010) De schilderijen, Nederlanders op het ijs. In: Roelofs P (ed) Hendrick Avercamp. De meester van het ijsgezicht, Rijksmuseum Amsterdam, pp 31-84 
Ryckaert M (1982) Hydrografie van de binnenstad en bloei van de middeleeuwse haven. In: Vermeersch V (eds) Brugge en de zee. Van Bryggia tot Zeebrugge. Mercator Fonds, Antwerpen, pp 27-74

Ryckaert M, vande Walle A (1982) De strijd voor het behoud van het Zwin. In: Vermeersch V (ed) Brugge en de zee. Van Bryggia tot Zeebrugge. Mercatorfonds, Antwerpen, pp 75-98

Unger R (1980) The Ship in the Medieval Economy, 600-1600. Croom Helm, McGrill-Queen's University Press, London, Montreal, pp 139-141

Uphoff R (2006). Emden 1490-1749. Quelleninventar der I. Registratur des Stadtarchivs Emden. Band I, Bearbeitet von Rolf Uphoff. Isensee Verlag Oldenburg

van Engelen AFV, Buisman J, Jnsen FI (2001) A millennium of weather, winds and water in the low countries. In: Jones PD, Ogilvie AEJ, Davies TD, Briffa KR (eds) History and Climate. Memories of the Future?. Kluwer Academic/Plenum Publishers, New York, Boston, pp 101-124 